\title{
STATISTICAL ANALYSIS OF THE POPULATION OF ECONOMIC AND SOCIAL OPERATORS: ROMANIA-FRANCE COMPARISON
}

\author{
Mihaela Diana OANCEA-NEGESCU ${ }^{a}$, Petrut Cristian VASILACHE ${ }^{b}$, \\ Oana Matilda SABIEc ${ }^{c}$ Ovidiu Andrei Cristian BUZOIANU ${ }^{d^{*}}$ \\ ${ }^{a, b, c, d}$ Bucharest University of Economic Studies
}

\begin{abstract}
Economic and social operators have always played a special role in the economic and social life of any country, being the basis of economic development. Dynamism, flexibility, adaptability, innovative potential are some of the characteristics that economic and social operators have and are considered important for the development of the economy of any state. They have played over time an important role in the development of the economy, by creating jobs, increasing competition and innovation, contributing to the dynamism and unity of the market. The positive effects generated by them are multiple, the most important are the improvement of the competitive environment, the creation of opportunities for development and adaptation to new technologies, the occupation of market niches that are not profitable for large companies. Economic and social operators have always been the main actor in the economic and social life of any nation, being the necessary basis for the development of the economy. The dynamic and flexible character, the adaptability, the innovative capacity represent some of the elements that they have and that are considered important for the harmonious progress of the economy of any state.The paper analyzes the importance of the development of companies in any market economy, the possible effects of the increase / decrease of this population on the economy of the respective countries, differences between the analyzed countries and presents the role of SMEs in the local economy.
\end{abstract}

KEYWORDS: development, economy, operators, society

JEL CLASSIFICATION: $C 15 ; C 46$

\section{DOI: 10.24818/IMC/2021/01.21}

\section{INTRODUCTION}

Economic and social operators have always been the main actor in the economic and social life of any nation, being the necessary basis for the development of the economy (Abad-Segura et al., 2019). The dynamic and flexible character, the adaptability, the innovative capacity represent some of the elements that they have and that are considered important for the harmonious progress of the economy of any state (Puiu, 2011). In each country, economic and social operators generate dynamism and profitability, have a role in increasing competitiveness, increasing the level of active employment (Appel et al., 2020).

Human resource development and the promotion of human capital by increasing adaptability and acquiring special skills required by the workplace are requirements arising from structural changes (Font et al., 2014). Human resource development is possible in terms of promoting lifelong learning as a principle and general framework for restructuring and developing education and training systems, ensuring key competences and coherence between formal, non-formal and informal

\footnotetext{
${ }^{*}$ Corresponding author. E-mail address: buzoianuovidiu@yahoo.com
} 
and support contexts human capital development. The modern market economy is based on preserving the principle of freedom of competition between operators who have the same or a similar objective in the market for goods o services, or in other market segments, presenting themselves with possible alternatives to consumers (Ghenea, 2011).

Strengthening the position of companies in the market involves mobilizing all the forces capable of streamlining the business and, ultimately, maximizing the profit - in the short term - and the value of the company- in the long term (Bodislav et al., 2020).Economic competition is approached as a condition and a guarantee of progress. The increasing apathy of abuses and anti-competitive practices, in the fight for economic power, for market domination, has made the issue of protecting economic competition subject to legal regulations and the institutionalization of prosecution and sanctioning procedures, repression of abuses that constitute violations. of the discipline defined by the observance of the rules of market normality (Profiroiu et al., 2020). In the two countries analyzed, economic and social operators have beneficial effects for the economic system, through the roles they play

\section{MANUSCRIPT}

\subsection{Effects of the increase or decrease of economic and social operators on the economy of the analyzed countries}

The performance of EU SMEs differs from country to country, depending on several factors, such as: the economic context, the divergent performance of Member States in terms of increasing value added and employment in SMEs., legislation, taxation, the level of development of the enterprise environment, economic recovery after the crisis, the effectiveness of economic policies adopted (Bansal \& DesJardine, 2014).

The most important factors influencing the development of SMEs and their performance are: the macroeconomic environment, which is the general economic climate- this includes aspects that directly or indirectly affect GDP and GDP growth, while capturing aspects related to the ability of economies to invest. for the future; structural features of the economy- which refer to the sectoral structure of the business economy in terms of technologies used by industry, the distribution of enterprises by size classes, how governments promote new technologies, public and private spending on research and development and innovation, as well as investments in innovation activities microeconomic factors- such as business demographics, entry and exit of/from the market of enterprises.

The SME sector is an important concern at EU level, given that SMEs are key factors in economic recovery (Popa, 2010). Between 2016 and 2020, 85\% of all emerging jobs in Europe were generated by small and medium-sized companies. During this period, the total employed population increased significantly, with an average of 1.2 million new jobs each year.

At European level, the contribution of SMEs to employment was $68.4 \%$, higher than that of large enterprises, $34.6 \%$. And the added value of gross SMEs is higher than that of large enterprises, even though it has fallen in the last two years as a result of the financial crisis (Stancu, 2002).

An important contribution of SMEs in 2019 was recorded in services and production, and the services sector attracted the largest number of employees, namely 84 million people, of which 56 million were employed in companies with less of 250 employees.

The data presented in Table 1 show that in 2016 over 144.000 SMEs suspended their activity compared to only 133.290 in 2020 . This trend has led to changes in the ratio between the number of suspensions and the number of deregistrations, from a superunitary one in 2016 and 2010, in a subunit one in 2020. 
Table 1. The evolution of SME registrations in Romania in the period 2016-2020

\begin{tabular}{|c|c|c|c|c|c|}
\hline Period & $\mathbf{2 0 1 6}$ & $\mathbf{2 0 1 7}$ & $\mathbf{2 0 1 8}$ & $\mathbf{2 0 1 9}$ & $\mathbf{2 0 2 0}$ \\
\hline Registration & 144.758 & 144.177 & 116.024 & 123.238 & 133.290 \\
\hline Cancellation & 20.451 & 50.022 & 63.481 & 184.227 & 71.975 \\
\hline Suspensions & 12.112 & 12.015 & 13.462 & 62.941 & 24.178 \\
\hline
\end{tabular}

Source: National Office of the Trade Register- Statistical summaries

In France, the analysis of economic agents according to the field in which they operate highlighted the following situation: service enterprises record the lowest firms that have reduced their activity (19.42\%) SMEs in a continuous upward slope (10.27\%), but also a higher percentage of companies that have restricted their activity (41\%) in the field of constructions, due to the high decline of this domain against the background of the decrease of the power of the population and the credit restrictions; SMEs in the field of transport register a higher share of companies that have maintained their volume of activity (36.81\%); the tourist units hold the percentage (10.34\%) of SMEs that have amplified their activity (see table 2 ).

Table 2. Dynamics of SME activity investigated in France during 2016-2020, depending on the branches of activity

\begin{tabular}{|l|c|c|c|c|c|c|}
\hline \multicolumn{1}{|c|}{ Crt. } & Industry & Construction & Trade & Transports & Tourism & Services \\
\hline $\begin{array}{l}\text { 1. SMEs that have reduced } \\
\text { their activity }\end{array}$ & $21,25 \%$ & $41 \%$ & $26,33 \%$ & $29,57 \%$ & $25,69 \%$ & $19,42 \%$ \\
\hline $\begin{array}{l}\text { 2. SMEs operating at the } \\
\text { same parameters }\end{array}$ & & & & & \\
\hline $\begin{array}{l}\text { 3. SMEs that have } \\
\text { amplified their activity }\end{array}$ & $10,56 \%$ & $5,35 \%$ & $3,87 \%$ & $5,54 \%$ & $10,11 \%$ & $10,25 \%$ \\
\hline
\end{tabular}

The data presented in Table 2 show that in France in 2016 about 25,300 SMEs were deregistered. In the next 3 years there is a rather significant increase, so in 2017 the number of write-offs increased by 22.724 compared to 2016, in 2018 by 3.399 compared to 2017, and in 2019 by 13.944 compared to 2018.

There is a rather significant decrease in the number of deregistrations in 2020, a decrease of 13.522 compared to 2019 , a decrease due to the economic recovery after a crisis that has left its mark on this sector.

The degree of suspension of activity was quite high, even in 2020 when the highest number of companies with suspended activity was registered compared to previous years (see table 1).

Table 3. The evolution of SME registrations in the period 2016-2020 in France

\begin{tabular}{|c|c|c|c|c|c|}
\hline Period & $\mathbf{2 0 1 6}$ & $\mathbf{2 0 1 7}$ & $\mathbf{2 0 1 8}$ & $\mathbf{2 0 1 9}$ & $\mathbf{2 0 2 0}$ \\
\hline Registration & 123.148 & 118.224 & 116.024 & 113.548 & 155.603 \\
\hline Cancellation & 25.300 & 48.024 & 51.423 & 65.267 & 51.745 \\
\hline Suspensions & 15.092 & 14.219 & 13.102 & 11.241 & 17.556 \\
\hline
\end{tabular}

Source: National Office of the Trade Register - Statistical summaries 


\subsection{Statistical analysis of the population of economic and social operators- comparison Romania-France}

This sub-item presents the structural statistics of enterprises, the description of the structure and the main characteristics of the performance of economic activities of two countries in the European Union: France and Romania.

The analysis of structured enterprise statistics is intended to provide answers on the population dynamics of economic and social operators, on the establishment rate, survival rate and bankruptcy rate of these economic and social operators (Anghelache, 2005). Business demography refers to events in the life cycle of an enterprise: establishment, development, survival or bankruptcy and their relationship to the business population (United Nations Economic Commission for Europe, 2018).

The study on the statistical analysis of economic and social operators was conducted in the period 2016-2020, based on official statistical data presented on Eurostat. The economic and social operators chosen according to the size and structure of enterprises are SMEs- small and medium-sized enterprises, as they have a specific utility on political decision-makers.

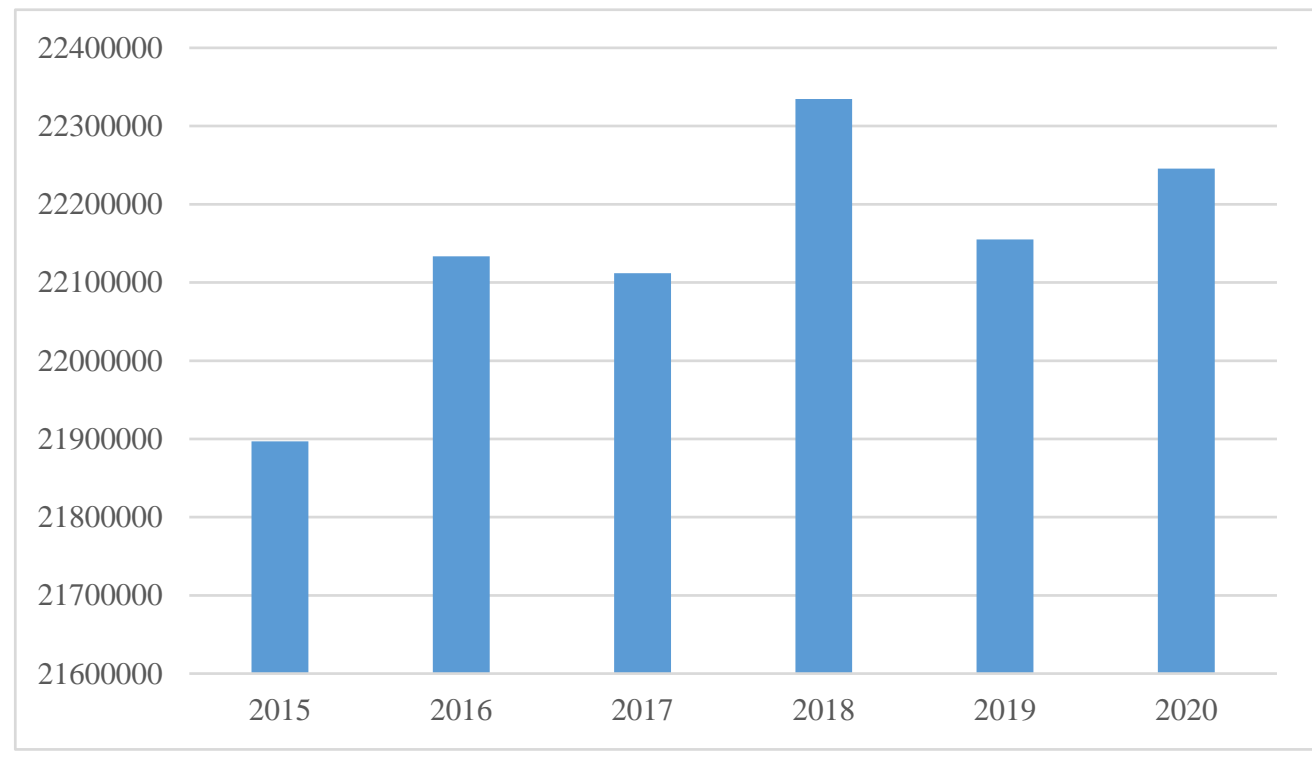

Figure 1. Number of SMEs in Europe

Source: EUROSTAT data

Businesses grow with age, so after five years the company has a medium or large size and a large share of employment (Fergnani, 2020).

Large enterprises are more involved in innovation than SMEs due to large budgets, but we note that in France the emphasis is more on organizational innovation than on marketing-based innovation (Carra et al., 2017), and in Romania the share is equal in marketing and organization, our country being-is in the bottom of the ranking (Nicolescu et al., 2012).

According to EUROSTAT, the average cost of labor in an hour is within the European Union varies from $€ 4.1$ to $€ 41.3$, with the lowest salaries being in Romania (€ 5.2) and Bulgaria (€ 4.3) and the highest salaries being in Denmark (€ 44.3), (€ 39.5), Sweden (€ 37.7), Luxembourg (€ 36.4) and France $(€ 35.4)$.

So globalization is the phenomenon of interconnectivity between nations, which involves a number of social and cultural elements, aiming more than the economic integration of the country, and SMEs are a key factor in this process (Faggianelli et al., 2018). 


\subsubsection{Analysis of the population dynamics of economic and social operators from 2016-2020}

The population dynamics of economic and social operators presupposes a general presentation of the population of business enterprises (Latapí Agudelo et al., 2019). There are important changes in the number of enterprises in the business economy from one year to another, changes that reflect the level of competition, entrepreneurship and business environment (Carra et al., 2018).

Business demographic statistics show the birth and death of an enterprise, as well as the average size of start-ups in terms of their employment (Rasmussen et al., 2019).

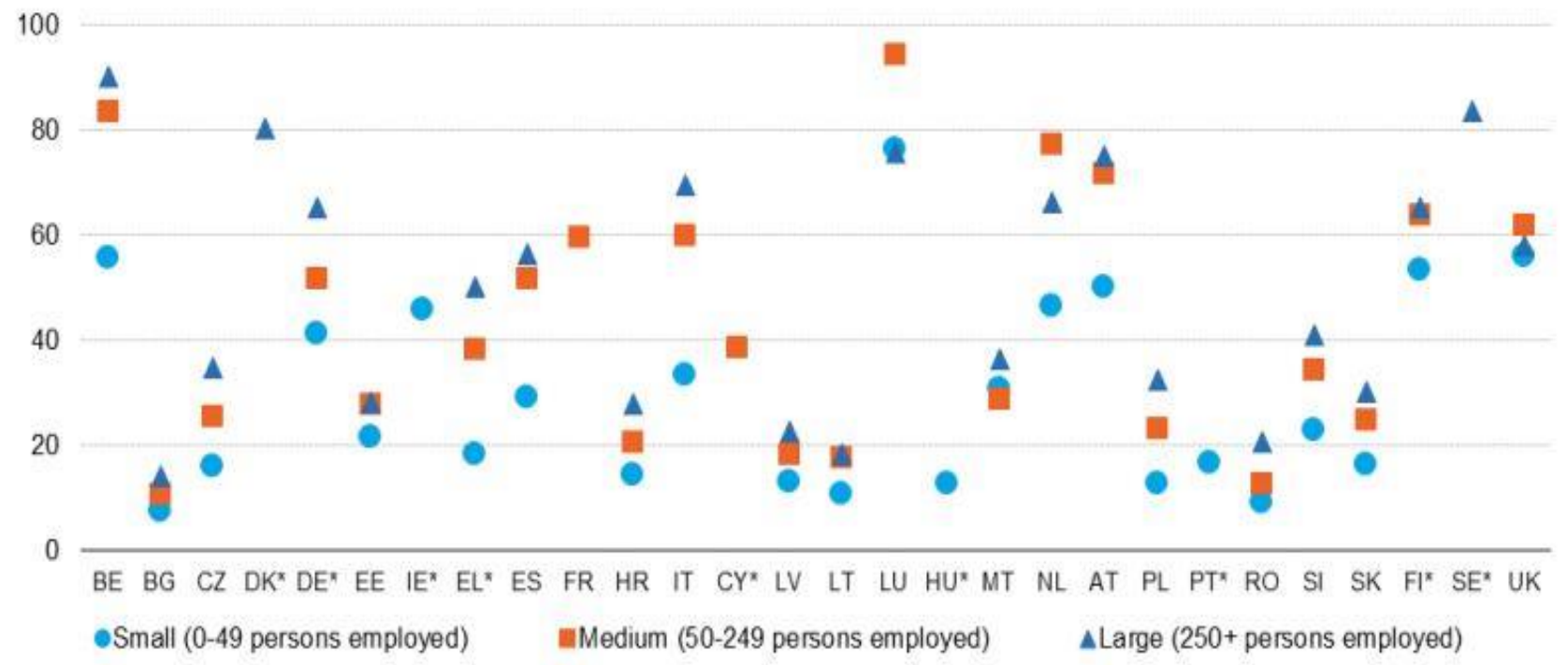

Figure 2. Value added $(€ 1,000)$ per employee, by size classes of the company Source: EUROSTAT data

Because most start-ups are small, the share of start-ups among the entire business enterprise population is much higher than the corresponding proportion of the workforce represented by these enterprises (Alpopi et al., 2018).

The distribution of value added by size classes is shown in Figure 2. Small enterprises usually account for $35 \%$ to $50 \%$ of total value added. The Czech Republic (34\%), Germany (33\%), Poland (31\%), Romania (30\%) and Ireland (28\%) are just below this time frame while Greece (56\%), Malta (54\%) and Italy $(51 \%)$ has higher values. Due to economies of scale, value added per employee is generally higher in large enterprises than medium-sized enterprises, followed by small enterprises.

\subsubsection{Analysis of the dynamics of the establishment rate of economic and social operators in the period 2016-2020}

The establishment of an enterprise represents the moment of starting the activity of an economicsocial operator, in order to create a combination of productive factors that will generate in the future profit, new jobs and economic sustainability (Li et al., 2020).

The establishment rate of an economic and social operator from a standard reference period, usually one calendar year, represents the number of established enterprises relative to the population of active enterprises (Bran et al., 2018).

Analyzing the dynamism in the economy provided by the rate of establishment of new economic and social operators we note that the rate of establishment of economic and social operators in Romania is $3.92 \%$ of France's share in 2016, decreasing in 2017 to $3.76 \%$. The year 2018 brings with it a significant increase in the rate, the number of companies that were born this year in Romania 
representing $9.32 \%$ of France's share. A year later, in France there are $6.33 \%$ more enterprises than in the previous year, and in Romania there are $9.56 \%$ less, so the share of our country is $7.9 \%$ of the percentage of France. The last year analyzed shows a better ratio between the two benchmark countries, Romania being $14.53 \%$ of the total French companies.

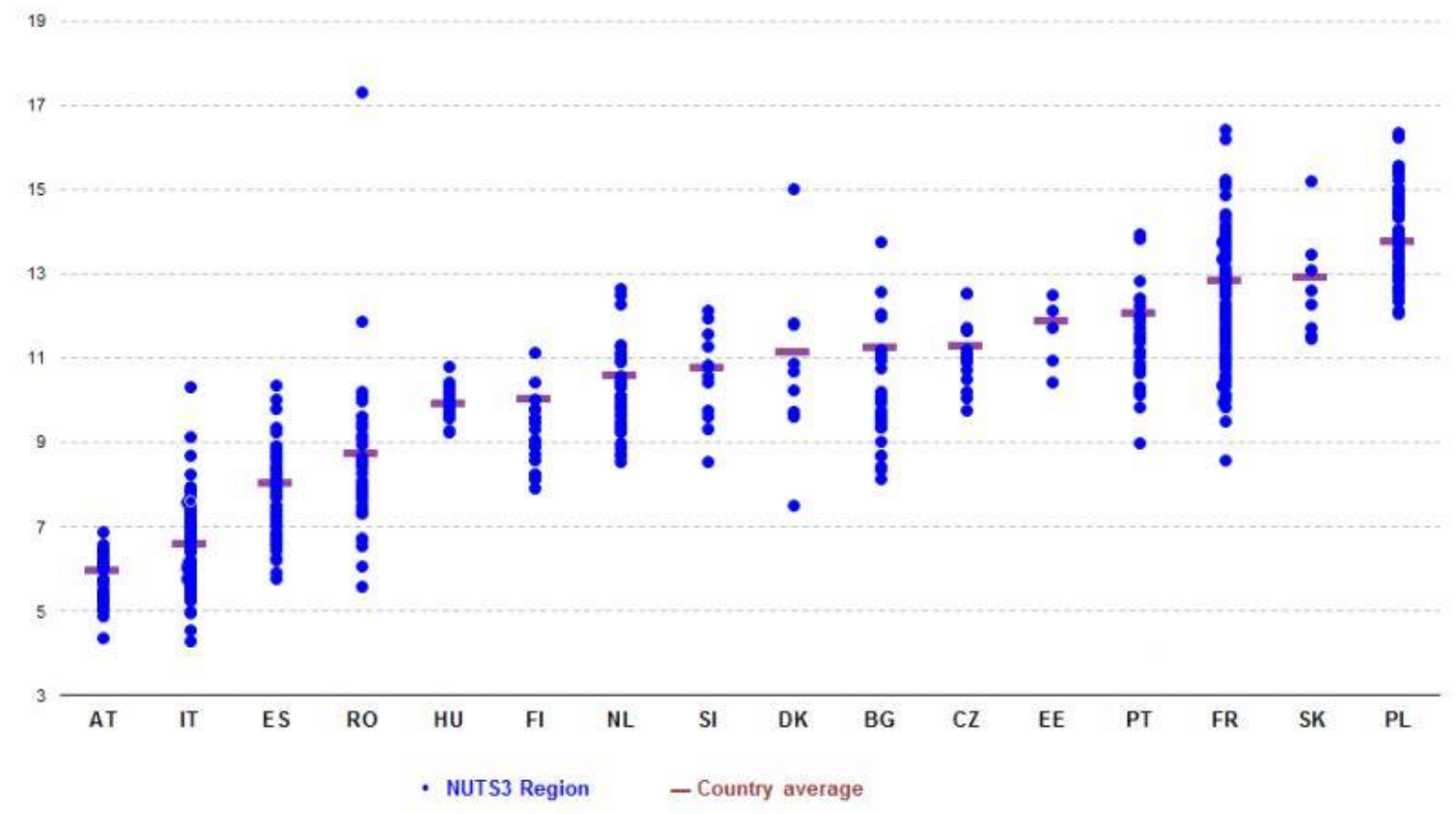

Figure 3. Business start-up rate in the world Source: EUROSTAT data

Analyzing the rate of establishment of economic and social operators in France, it seems that the business economy has experienced a drastic decline from 3354 enterprises in 2016 to 3284 enterprises in 2017. After this year, there has been an increase in the number of new companies -established, so that in 2018, 3490 individuals eager to put their dreams into practice and support their country have opened their desired businesses. The year $2020 \mathrm{kept}$ about the same share of newly established companies, and the standard country, France, enjoyed a long-term economic support.

Analyzing the establishment rate of economic and social operators in Romania, it can be said that the business economy has experienced an increase in number of newly established enterprises in the period 2016-2020.

Drawing a parallel between the standard countries, namely France and Romania, it can be seen that in France the number of start-ups is constant due to the entrepreneurial status offered by this country so that the individual can test the business before creating a structure. applies VAT, he cannot invoice VAT and cannot recover his VAT from suppliers, and the main advantage is that if he does not record a monthly or quarterly turnover, he does not pay any contributions to the state.

In Romania, the number of newly established enterprises increased in 2020 due to the new generation of entrepreneurs who took the risk of a business in Romania and became flexible and creative (Rădulescu et al., 2020). But Romania has developed four types of entrepreneurs: those who run real businesses and do not depend on political contracts, those who have developed a relationship of dependence on the state, those who have mixed businesses and those who manage state-owned enterprises. Romanian. 


\section{CONCLUSIONS}

Economic and social operators have always played a special role in the economic and social life of any country, being the basis for economic development. Dynamism, flexibility, adaptability, innovative potential are some of the characteristics that economic and social operators have and are considered essential for the development of the economy of any state.

The positive effects generated by them are multiple, the most important are the improvement of the competitive environment, the creation of opportunities for development and adaptation to new technologies, the occupation of market niches that are not profitable for large companies.

Economic and social operators have always been the main actor in the economic and social life of any nation, being the necessary basis for the development of the economy. The dynamic and flexible character, the adaptability, the innovative capacity represent some of the elements that they have and that are considered important for the harmonious progress of the economy of states.

Businesses grow with age, so after five years the company has a medium or large size and a large share of employment. Large enterprises are more involved in innovation than SMEs due to large budgets, but we note that in France the emphasis is more on organizational innovation than on marketing-based innovation, and in Romania the share is equal between marketing and organizational, our country being at the bottom of the rankings.

Analyzing the survival rate in the period 2016-2020 in Romania, it was found that 2017 saw a lower survival rate of companies due to external economic factors that have manifested themselves worldwide.

Drawing a parallel between the standard countries- France and Romania, we find that in France the number of surviving companies is constantly growing due to measures to improve business conditions adopted by the French state by reducing taxes paid by the employer.

In Romania, the number of surviving enterprises is increasing year by year, although the SME sector is poorly developed compared to other countries in the European Union, respectively compared to France.

The average in Romania is 30 enterprises per 1000 individuals compared to the European average of 60 enterprises per 1000 individuals. This survival can be attributed to the European funds that were contracted by Romanian entrepreneurs.

\section{ACKNOWLEDGMENT}

Thanks to the team for their help in writing this article. I would like to thank the EUROSTAT for their assistance with the statistics used in this report. I would like to express my deep gratitude to my colleagues for their continued encouragement, critical analysis of this article and guidance.

\section{REFERENCES}

Abad-Segura, E., Cortes-Garcia, F.J., \& Belmonte-Urena, L.J. (2019). The sustainable approach to Corporate Social Responsibility: A global analysis and future trends. Sustainability 11, 5382

Alpopi, C., Burlacu, S., \& Ioviţu, M. (2018). The process of globalization and environmental policies. Competitiveness and Innovation in the Knowledge Economy 2, September 28-29, 2018, Chișinău, Republic of Moldova: ASEM Publishing-Printing Department, 2018, pp. 317-324. ISBN 9789975-75-931-1

Anghelache, C., Badea, S.G., \& Wagner P. (2005). Bazele statisticii teoretice şi economice, Bucharest: Ed. Economică 
Appel, G., Grewal, L., Hadi, R., \& Stephen, A.T. (2020). The future of social media in marketing. J. Acad. Mark. Sci, 48, 79-95.

Bansal, P., \& DesJardine, M.R. (2014). Business sustainability: It is about time. Strategic Organization, 12(1), 70-78.

Bodislav, D. A., Buzoianu, O. A. C., Burlacu, S., \& Rădulescu, C. V. (2020). Analysis of companies in Romania from the perspective of risk perception and the management needs thereof. Economic Convergence in European Union, 341.

Bran, F., Alpopi, C., \& Burlacu, S. (2018). Territorial Development-Disparities between the Developed and the least Developed Areas of Romania. LUMEN Proceedings, 6(1), 146-155.

Carra, C., Burlacu, S., \& Faggianelli, D. (2017). Violence in health organizations in Romania. The 13th Administration and Public Management International Conference. Policy And Organizational Change In Public Institutions, București, Romania. 〈hal-01698150〉

Carra, C., Burlacu, S., \& Faggianelli, D. (2018). Violence within the organizations of health and medico-social sector. A comparative analysis of France and Romania. Economics, Management and Financial Markets, 13(3), 185-202.

Faggianelli, D., Burlacu, S., \& Carra, C. (2018). Victimization of Health Professionals in Bucharest Service Relations and Social Work Relationships. Administratie si Management Public 30, 109126.

Fergnani, A. (2020). Corporate foresight: A new frontier for strategy and management. Acad. Manag. Perspect. in press.

Font, X., Garay, L., \& Jones, S. (2014). Sustainability motivations and practices in small tourism enterprises in European protected areas. Journal of Cleaner Production, 137, 1439-1448.

Ghenea, M., (2011), Antreprenoriat- Drumul de la idei către oportunităţi şi succes în afaceri, Ed. Universul Juridic, Bucureşti

Latapí Agudelo, M.A., Jóhannsdottir, L., \& Davídsdóttir, B. (2019). A literature review of the history and evolution of corporate social responsibility. Int. J. Corp. Soc. Responsib.

Li, Z., Nan, G., \& Li, M. (2020). Advertising or freemium: The impacts of social effects and service quality on competing platforms. IEEE Trans. Eng. Manag., 67, 220-233

Nicolescu, O., Haiduc, I.C., \& Nancu, D., (2012). Carta Albă a IMM-urilor din România, Ed. Sigma, București

Popa, I. (2010). Management intraprenorial, Ed. ASE, Bucureşti

Profiroiu, C. M., Bodislav, D. A., Burlacu, S., \& Rădulescu, C. V. (2020). Challenges of Sustainable Urban Development in the Context of Population Growth. European Journal of Sustainable Development, 9(3), 51-51.

Puiu, A. (2011). Politica socială a întreprinderii, Piteşti: Ed.Independenţa Economică

Rasmussen, S., Talla, M., \& Valverde, R. (2019). Case study on geocoding based scheduling optimization in supply chain operations management. WSEAS Trans. Comput. Res. 7, 29-35

Rădulescu, C. V., Bran, F., Burlacu, S., Dobrea, C. R., \& Diaconu, S. (2020). Challenges Regarding Food Resources in the Context of Globalization and Population Growth. In Proceedings of the International Conference on Economics and Social Sciences (pp. 1041-1052). Sciendo.

Stancu, I. (2002). Analiza şi gestiunea financiară a întreprinderii, Bucharest: Ed. Economică

United Nations Economic Commission for Europe (2018). Guidelines on the use of statistical business registers for business demography and entrepreneurship statistics. United Nations New York and Geneva. Retrieved from https://unece.org/fileadmin/DAM/stats/publications/2018/ECECESSTAT20185.pdf 